\title{
INFLUENCE OF THE TOOL GEOMETRY AND PROCESS PARAMETERS ON THE STATIC STRENGTH AND HARDNESS OF FRICTION-STIR SPOT-WELDED ALUMINIUM-ALLOY SHEETS
}

\author{
VPLIV GEOMETRIJE ORODJA IN PARAMETROV PROCESA NA \\ STATIČNO TRDNOST IN TRDOTO PRI VRTILNO-TORNEM \\ TOČKASTEM VARJENJU PLOČEVIN IZ Al-ZLITINE
}

\author{
Hande Güler \\ Uludag University, Faculty of Engineering, Department of Mechanical Engineering, 16059 Gorukle-Bursa, Turkey \\ handeguler@uludag.edu.tr \\ Prejem rokopisa - received: 2014-06-07; sprejem za objavo - accepted for publication: 2014-07-22
}

doi: $10.17222 /$ mit.2014.087

In this study, the effects of the tool geometry and welding parameters on the friction-stir spot-welding properties of AA 5754-H111 were studied. Two different tool-pin geometries were used and tensile shear tests were carried out to compare the weld strength. Hardness observations were also done. The optimum tool geometry for the mentioned material was determined as the circular pin tool and the tapered pin tool gave the lowest tensile shear load.

Keywords: Al-alloys, friction-stir spot welding, mechanical properties, hardness

V tej študiji so bili preučevani vplivi geometrije orodja in parametrov varjenja na torno- vrtilno točkasto varjenje zlitine AA 5754-H111. Dve različni geometriji konice orodja sta bili uporabljeni in opravljeni so bili natezni strižni preizkusi za primerjavo trdnosti zvara. Opravljene so bile tudi meritve trdote. Za ta material je bilo ugotovljeno, da je optimalna geometrija orodja $\mathrm{v}$ obliki okrogle konice, pri stožčasti konici orodja pa je bila ugotovljena najmanjša strižna trdnost.

Ključne besede: Al-zlitine, torno-vrtilno točkasto varjenje, mehanske lastnosti, trdota

\section{INTRODUCTION}

Friction-stir spot welding (FSSW) is an alternative method for spot welding of lightweight alloys that was developed by Mazda Motor Corporation and Kawasaki Heavy Industries in 2003. ${ }^{1}$ The FSSW method consists of three phases: plunging, stirring and retraction. In these phases, a cylindrical rotating tool plunges at a specific rate into the overlapping sheets to a predetermined depth. It is then retracted at a rapid rate either immediately or after a dwell period. The heating is achieved with the friction between the tool and the workpieces causing a plastic deformation of the workpieces. The localized heating softens the material around the pin and the forging pressure applied with the tool shoulder results in the formation of an annular, solid-state bond around the pin. The retraction of the pin leaves a characteristic exit hole. ${ }^{2}$

The significant parameters that determine the strength of FSSW joints are the rotational speed, the dwell time and the tool plunge depth and this method has been successfully applied to aluminum, magnesium, advanced high-strength steel and polymers. ${ }^{3}$ There have been several papers relating to different FSSW process parameters and different materials.

Külekçi ${ }^{4}$ investigated the effects of the FSSW parameters such as the tool rotation, the dwell time and the tool-pin height on the tensile shear strength of an EN
AW 5005 aluminium alloy and determined the optimum parameters. Tozaki et al. ${ }^{5}$ proposed a new tool which uses a scroll groove to displace the material in the vertical direction instead of the profiled pin and compared it with the conventional convex-shoulder tool with a cylindrical pin. They found that the new tool exhibited equal, or superior, results compared with the conventional tool.

FSSW of an Al-alloy 6016-T4 sheet was evaluated by Yuan et al. ${ }^{6}$ using the conventional pin tool and offcenter feature tool. Different parameters were investigated to determine the lap-shear separation load and they found that the tool rotational speed and plunge depth influenced the shear strength. Badarinarayan et al. ${ }^{7}$ studied the effects of the shoulder and pin geometry on the hook formation, and the material flow of a frictionstir spot-welded 5754-O aluminum alloy was investigated. Külekçi et al. ${ }^{8}$ explored the hardness distribution and the tensile shear strength of FSSW welds of the EN AW 5005 aluminum alloy and compared them with resistance spot welding.

The effects of three tool shapes (threaded-pin tool: TPT; cylindrical tool: CT; cylindrical tool with projection: CTP) and the tool penetration depth on the joint strength of a FSSW commercial AA 5J32 alloy with a nominal composition in mass fractions $(w / \%)$ of Al-5.54Mg-0.03Si-0.07Fe-0.32Cu-0.03Ti-0.01Zn was investigated by Choi et al. ${ }^{9}$ The CTP (cylindrical tool 
Table 1: Chemical composition of the investigated material in mass fractions, $w / \%$

Tabela 1: Kemijska sestava preiskovanega materiala v masnih deležih, w/\%

\begin{tabular}{|c|c|c|c|c|c|c|c|c|c|}
\hline & $\mathrm{Si}$ & $\mathrm{Fe}$ & Mn & $\mathrm{Mg}$ & $\mathrm{Cu}$ & $\mathrm{Ti}$ & $\mathrm{Cr}$ & $\mathrm{Zn}$ & $\mathrm{Al}$ \\
\hline Chemical composition & 0.071 & 0.251 & 0.19 & 2.834 & 0.022 & 0.003 & 0.024 & 0.049 & Balance \\
\hline
\end{tabular}

with projection) showed the best mechanical properties compared to the other tool shapes.

Karthikeyan and Balasubramanian ${ }^{10}$ aimed at optimizing the welding parameters to attain the maximum lap-shear tensile strength of a friction-stir spot-welded AA2024 aluminum alloy. For this purpose, an empirical relationship was developed to predict the tensile shearfracture load.

In this work, the FSSW process was used with the objective to investigate the effects of different welding parameters and tool geometry on the mechanical performance of thick AA 5754-H111 $1 \mathrm{~mm}$. This alloy has been widely used in shipbuilding, the vehicle, chemical and nuclear industries. ${ }^{11}$

However, a literature review indicated that there is only one paper about the thick AA 5754-H111 $1 \mathrm{~mm} .{ }^{12}$ Güler ${ }^{12}$ studied the FSSW process of the thick AA 5754-H111 $1 \mathrm{~mm}$ using only circular pinned tool. In this context, the effects of the tool design and process parameters on the weld strength and hardness distribution were studied and the effects of FSSW process were compared using the tools with circular and tapered pins.

\section{EXPERIMENTAL DETAILS}

Commercially available aluminium-alloy plates (AA 5754-H111) with a thickness of $1 \mathrm{~mm}$ were used to fabricate the joints. The chemical composition of the material is presented in Table $\mathbf{1}$. The tensile strength, the yield strength and the elongation are $207 \mathrm{MPa}, 117 \mathrm{MPa}$ and $21 \%$, respectively. The samples for the tensile shear test were machined out with the dimensions of $105 \mathrm{~mm}$ $\times 45 \mathrm{~mm} \times 1 \mathrm{~mm}$ according to the ISO 14273 standard. The specimens were lap positioned with a $45 \mathrm{~mm} \times 45$ $\mathrm{mm}$ overlap area (Figure 1). The welded samples were loaded on a universal testing machine with a constant crosshead of $5 \mathrm{~mm} / \mathrm{min}$ and with a load capacity of 250 $\mathrm{kN}$.

FSSW was performed using two different tools made of hot-work tool steel having different pin profiles: a circular one, designated as FSSW-C and a tapered one, designated as FSSW-T. The tools with different pin

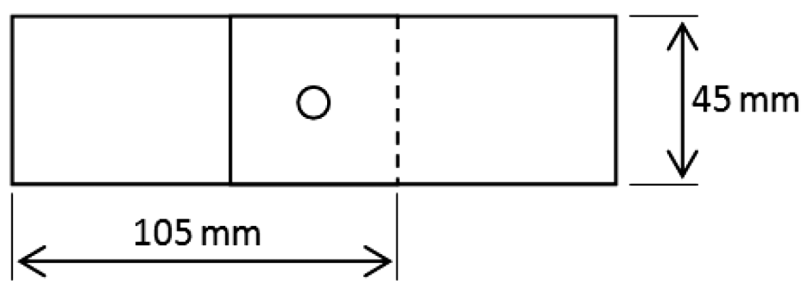

Figure 1: Lap-shear specimen

Slika 1: Vzorec s prekrivanjem za strig geometries were selected to ensure simple manufacturing with a small amount of tool wear. As shown in Figure 2, each tool had a shoulder with a diameter of $15 \mathrm{~mm}$ and a pin length of $1.7 \mathrm{~mm}$. The circular pin had a diameter of $5 \mathrm{~mm}$ and the tapered pin had the diameters of $5 \mathrm{~mm}$ at the bottom and $7 \mathrm{~mm}$ at the pin shoulder.

The prepared samples were joined by FSSW using different tool rotational speeds and dwell times. FSSW was performed at three tool rotational speeds, ranging from $500 \mathrm{r} / \mathrm{min}$ to $1500 \mathrm{r} / \mathrm{min}$, while the plunge depth of the tool pin was $1.8 \mathrm{~mm}$ and the dwell time ranged from $6 \mathrm{~s}$ to $21 \mathrm{~s}$. Considering each parameter, five joints at different tool rotational speeds and dwell times were produced and tested. Some samples of the FSSW joints are shown in Figure 3.

\section{RESULTS AND DISCUSSION}

\subsection{Tensile shear strength}

Figure 4 shows a comparison of the shear load versus the dwell time obtained during the shear tensile testing at a constant tool rotational speed. According to Figure 4a, both the dwell time and the shear load of the FSSW-C welds increased, while the shear load of the FSSW-T welds remained almost constant. When using the tapered tool with a combination of a tool rotational speed $500 \mathrm{r} / \mathrm{min}$ and dwell time $6 \mathrm{~s}$, the shear load increased by $55 \%$. Besides, at the other dwell times, the shear loads of the FSSW-C welds were higher compared to those of the FSSW-T welds.

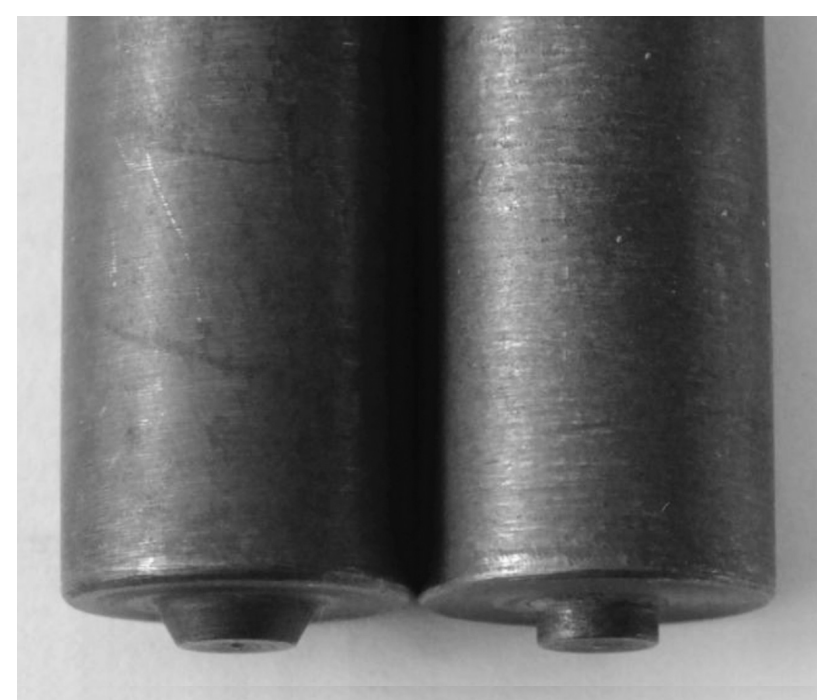

Figure 2: Two types of tool used for FSSW: FSSW-T (tapered pin, left) and FSSW-C (circular pin, right)

Slika 2: Dve vrsti orodja, uporabljeni za FSSW: FSSW-T (konica v obliki prisekanega stožca, levo) in FSSW-C (okrogla konica, desno) 

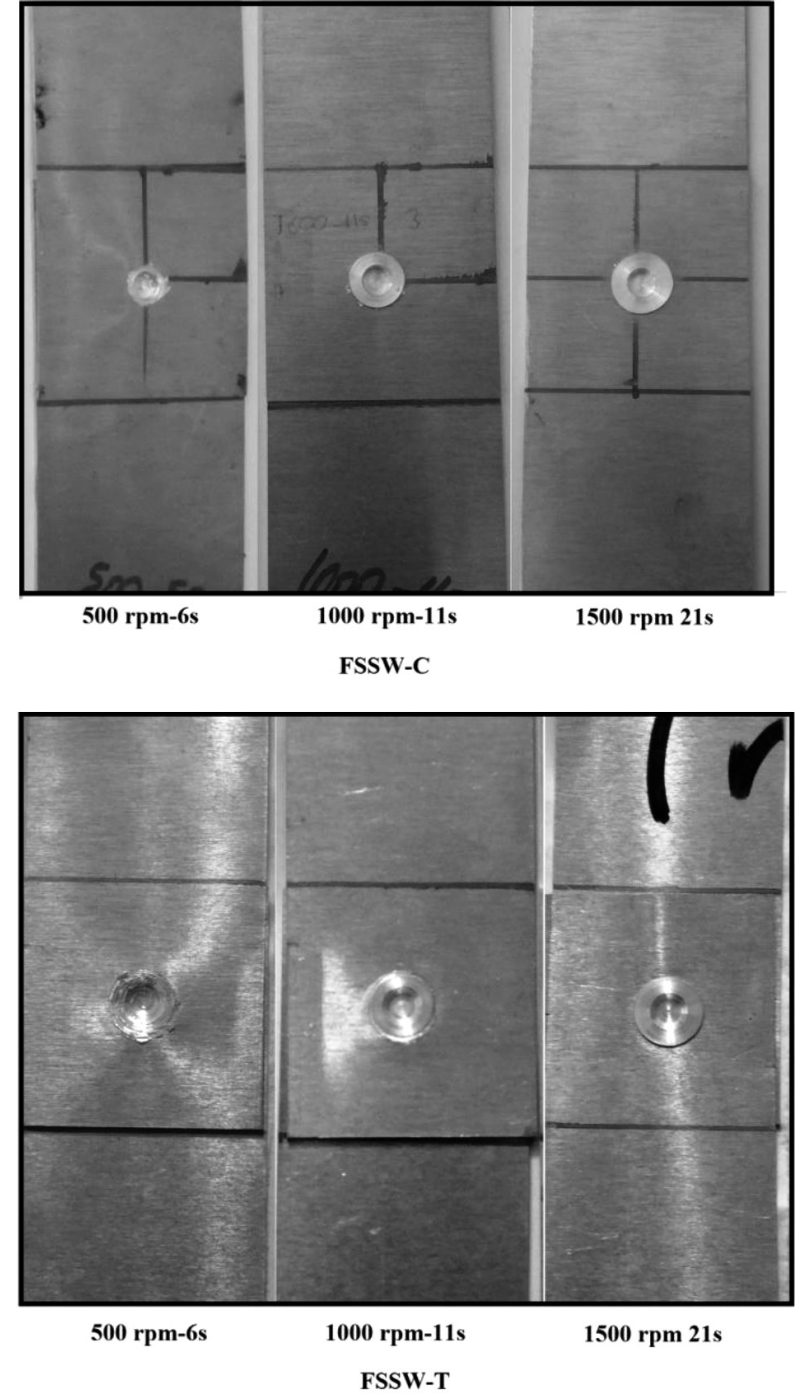

Figure 3: Samples of friction-stir spot-welded joints

Slika 3: Vzorci vrtilno-torno točkasto zvarjenih spojev

Figure 4b shows the shear-load values at a tool rotational speed $1000 \mathrm{r} / \mathrm{min}$. According to the figure, the average shear loads of the FSSW-C welds are higher than the ones of the FSSW-T welds. With the combination of the tool rotational speed $1000 \mathrm{r} / \mathrm{min}$ and dwell time $11 \mathrm{~s}$, the maximum increase was observed when using the circular tool which increased the shear load by approximately $43 \%$.

The tensile-shear-test results for $1500 \mathrm{r} / \mathrm{min}$ are given in Figure 4c. An increase in the dwell time from $6 \mathrm{~s}$ to $21 \mathrm{~s}$ increased the tensile shear load of the FSSW-T welds by $26 \%$, while the tensile shear load of the FSSW-C welds remained almost constant. On the other hand, the shear-load values were higher when a sample was welded with the FSSW-C tool compared with the FSSW-T tool.

According to all the tensile shear results, the specimens welded with the FSSW-C tool exhibited an increase in the shear load. The results of the previous investigations $^{7,13,14}$ stated that the tool-pin geometry
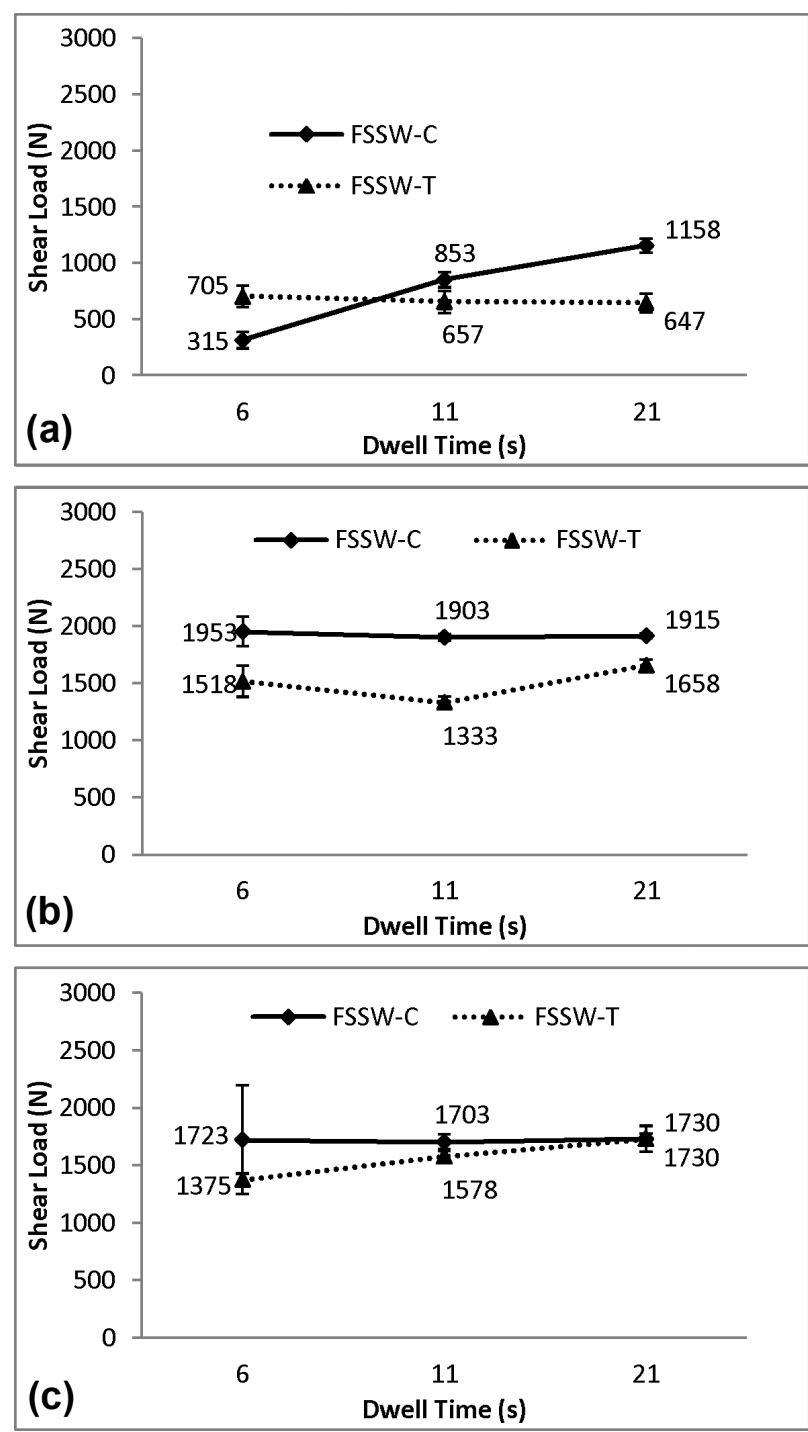

Figure 4: Shear load as a function of dwell time for both FSSW-C and FSSW-T welds at a tool rotational speed: a) $500 \mathrm{r} / \mathrm{min}$, b) $1000 \mathrm{r} / \mathrm{min}$, c) $1500 \mathrm{r} / \mathrm{min}$

Slika 4: Strižna obremenitev v odvisnosti od časa zadrževanja za obe varjenji: FSSW-C in FSSW-T pri hitrosti orodja: a) 500 r/min, b) 1000 $\mathrm{r} / \mathrm{min}$, c) $1500 \mathrm{r} / \mathrm{min}$

significantly affects the hook geometry and thereby the shear-load capacity of FSSWs. An increase in the tensile shear load may be explained with the microstructural changes due to the heat generation at a stirring location. ${ }^{4}$ When using a FSSW-T tool, the materials may be stirred severely and extensively. When the amount of the material stirred is large, the size of a bonded region also becomes large, resulting in a higher separation load. ${ }^{14}$

\subsection{Microhardness}

Hardness measurements were performed on a Vickers microhardness tester focusing at the medium-thick area of the upper sheet with a load of $100 \mathrm{~g}$, dwell time of 10 $\mathrm{s}$ and spacing of $1 \mathrm{~mm}$. The microhardness-distribution examples of the FSSW-C and FSSW-T welded joints are 

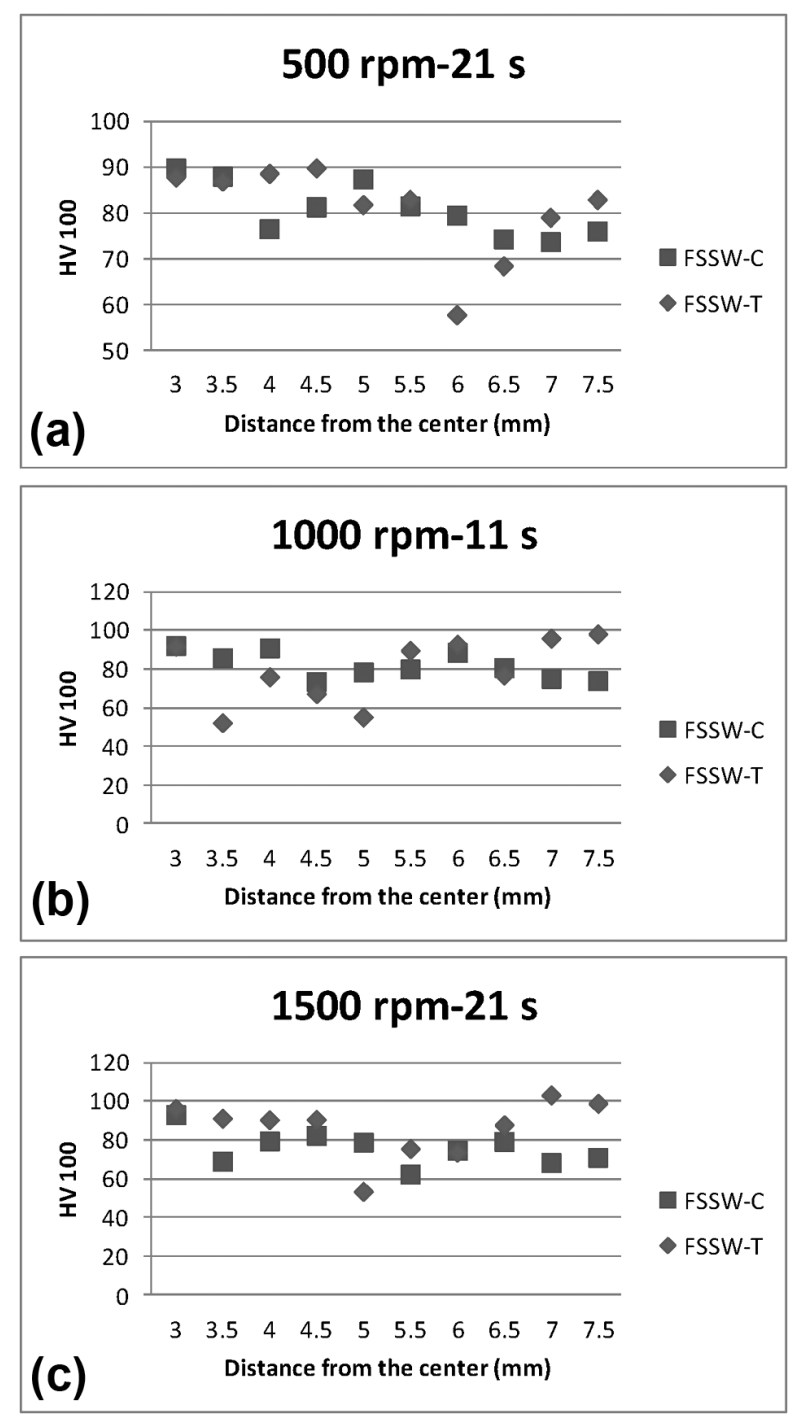

Figure 5: Hardness distribution for both FSSW-C and FSSW-T welds with a combination of: a) $500 \mathrm{r} / \mathrm{min}$ and $21 \mathrm{~s}$, b) $1000 \mathrm{r} / \mathrm{min}$ and $11 \mathrm{~s}$, c) $1500 \mathrm{r} / \mathrm{min}$ and $21 \mathrm{~s}$

Slika 5: Razporeditev trdote za oba zvara FSSW-C in FSSW-T pri kombinaciji: a) $500 \mathrm{r} / \mathrm{min}$ in zadržanju $21 \mathrm{~s}$, b) $1000 \mathrm{r} / \mathrm{min}$ in $11 \mathrm{~s}$, c) $1500 \mathrm{r} / \mathrm{min}$ in $21 \mathrm{~s}$

given in all the hardness profiles, and a higher Vickers microhardness was observed close to the keyhole because of a higher plastic deformation, which also caused very fine, dynamic recrystallized grains. On the other hand, in the region close to the keyhole, the FSSW-T weld had a slightly higher hardness than the FSSW-C weld. This situation occurred because of the presence of a finer grain structure observed in the stir zone of the FSSW-T weld. ${ }^{13}$ In addition, on the basis of Figures $\mathbf{5 a}, \mathbf{5 b}$ and $\mathbf{5 c}$, it was concluded that the hardness distribution was somewhat scattered without a noticeable trend. There was no obvious influence of the process parameters on the hardness distribution. ${ }^{4}$

\section{CONCLUSIONS}

In this work, the mechanical properties of the AA 5754-H111 aluminum-alloy material were investigated during the FSSW process. The welding process was performed using two different types of designed tools (FSSW-C and FSSW-T), compared to each other. After analyzing the experimental results, the following conclusions can be drawn:

1. At the tool rotational speed $500 \mathrm{r} / \mathrm{min}$, the dwell time is an influential factor in determining the tensile shear load of the FSSW-C welds, while the tensile shear loads remain almost constant at the other tool rotational speed. When using the FSSW-T tool at the rotational speed $1500 \mathrm{r} / \mathrm{min}$, the tensile shear load increases if the dwell time increases.

2. Higher shear-load values are found for the sample welded with the FSSW-C tool, compared to the FSSW-T tool, because of a better stirring procedure.

3 . There are no noticeable effects of the tool geometries and welding parameters affecting the hardness of the mentioned material.

4. As future work, different failure modes occurring during the lap-shear test could be studied to determine their effects on the tensile shear-load capacity.

\section{REFERENCES}

${ }^{1} \mathrm{~W}$. Ratanathavorn, Hybrid Joining of Aluminum to Thermoplastics with Friction Stir Welding, Master of Science Thesis, Department of Materials Science and Engineering, KTH - Royal Institute of Technology [cited 2014-07-06], available from http://kth.diva-portal.org/ smash/get/diva2:515154/FULLTEXT01.pdf

${ }^{2}$ S. Lathabai, M. J. Painter, G. M. D. Cantin, V. K. Tyagi, Scripta Materialia, 55 (2006), 899-902, doi:10.1016/j.scriptamat.2006.07.046

${ }^{3}$ X. Song, L. Ke, L. Xing, F. Liu, C. Huang, The International Journal of Advanced Manufacturing Technology, 71 (2014) 9-12, 20032010, doi:10.1007/s00170-014-5632-y

${ }^{4}$ M. K. Külekçi, Archives of Metallurgy and Materials, 59 (2014) 1, 221-224, doi:10.2478/amm-2014-0035

${ }^{5}$ Y. Tozaki, Y. Uematsu, K. Tokaji, Journal of Materials Processing Technology, 210 (2010), 844-851, doi:10.1016/j.jmatprotec.2010. 01.015

${ }^{6}$ W. Yuan, R. S. Mishra, S. Webb, Y. L. Chen, B. Carlson, D. R. Herling, G. J. Grant, Journal of Materials Processing Technology, 211 (2011), 972-977, doi:10.1016/j.jmatprotec.2010.12.014

${ }^{7}$ H. Badarinarayan, Y. Shi, X. Li, K. Okamoto, International Journal of Machine Tools \& Manufacture, 49 (2009), 814-823, doi:10.1016/ j.ijmachtools.2009.06.001

${ }^{8}$ M. K. Külekci, U. Esme, O. Er, Mater. Tehnol., 45 (2011) 5, 395-399

${ }^{9}$ D. Choi, B. Ahn, C. Lee, Y. Yeon, K. Song, S. Jung, Materials Transactions, 51 (2010) 5, 1028-1032, doi:10.2320/matertrans. M2009405

${ }^{10}$ R. Karthikeyan, V. Balasubramanian, Int. J. Adv. Manuf. Technol., 51 (2010), 173-183, doi:10.1007/s00170-010-2618-2

${ }^{11}$ T. S. Mahmoud, T. A. Khalifa, JMEPEG, 23 (2014), 898-905, doi:10.1007/s11665-013-0828-0

${ }^{12}$ H. Güler, JOM, 66 (2014) 10, 2156-2160, doi:10.1007/s11837014-1117-6

${ }^{13}$ H. Badarinarayan, Q. Yang, S. Zhu, International Journal of Machine Tools \& Manufacture, 49 (2009) 2, 142-148, doi:10.1016/ j.ijmachtools.2008.09.004

${ }^{14}$ N. Pathak, K. Bandyopadhyay, M. Sarangi, S. K. Panda, Journal of Materials Engineering and Performance, 22 (2013), 131-144, doi:10.1007/s11665-012-0244-x 